\title{
Determinants of Dividend Payout Ratios: Evidence from United States
}

\author{
Amarjit Gill $^{*}, 1$, Nahum Biger ${ }^{2}$ and Rajendra Tibrewala ${ }^{3}$ \\ ${ }^{1}$ College of Business Administration, TUI University, CA 90630, USA \\ ${ }^{2}$ Academic Center Carmel, Shaar Palmer 4, Haifa, 33031, Israel \\ ${ }^{3}$ School of Management, New York Institute of Technology, Old Westbury, NY 11568, USA
}

\begin{abstract}
The paper seeks to extend Amidu and Abor [1] and Anil and Kapoor [2] findings regarding the determinants of dividend payout ratios by examining the same for the American service and manufacturing firms. We find that for the entire sample the dividend payout ratio is the function of profit margin, sales growth, debt-to-equity ratio, and tax. For firms in the Services industry the dividend payout ratio is the function of profit margin, sales growth, and debt-to-equity ratio. For manufacturing firms we find that dividend payout ratio is the function of profit margin, tax, and market-to-book ratio. We also found that the results are different when the dividend payout ratio is defined as the ratio between the cash dividend that the after-tax cash flow, not the after tax earnings of the companies.
\end{abstract}

Keywords: Dividends, determinants, finance and accounting, United States.

\section{INTRODUCTION}

Dividend payout has been a subject of debate in financial literature. Academicians and researchers have developed many theoretical models describing the factors that managers should consider when making dividend policy decisions. The dividend policy, in the context of this study, means the payout policy that managers follow in deciding the size and pattern of cash distribution to shareholders over time. In their seminal paper, Miller and Modigliani [3] argue that given perfect capital markets, the dividend decision does not affect the firm value and is, therefore, irrelevant. Most financial practitioners and many academics greeted to this conclusion with surprise because the conventional wisdom at the time suggested that a properly managed dividend policy had an impact on share prices and shareholders' wealth.

Company's income can be invested in operating assets, used to acquire securities, used to retire debt, and/or distributed to shareholders in the form of cash dividends. Issues that arise if a company decides to distribute its income to shareholders include the proportion of the after tax income would be distributed to shareholders; whether the distribution should be as cash dividends, or the cash be passed on to shareholders by buying back some shares; and how stable the distribution should be. In the well known classical paper Black [4] argues that "the harder we look at the dividends picture, the more it seems like a puzzle, with pieces that just do not fit together." Since the publication of Black's paper, the amount of theoretical and empirical research on dividend policy has increased dramatically. Bernstein [5], and Aivazian and Booth [6] revisited the dividend puzzle and found that some important questions remained unanswered. Thus setting corporate dividend policy remains controversial and involves judgment by

*Address correspondence to this author at the College of Business Administration, TUI University, CA 90630, USA; Tel: 604-985-8736; Fax: 714-816-0367; E-mail: agill@tuiu.edu decision makers. In addition, there has been emerging consensus that there is no single explanation of dividend payments.

There are many reasons as to why companies should pay or not to pay dividends. For example, the dividend payout is important for investors because i) dividends provide certainty about the company's financial well-being, ii) dividends are attractive for investors looking to secure current income, and iii) dividends help maintain market price of the share. Companies that have a long-standing history of stable dividend payouts would be negatively affected by lowering or omitting dividend distributions. These companies would be positively affected by increasing dividend payouts or making additional payouts of the same dividends. Furthermore, companies without a dividend history are generally viewed favorably when they declare new dividends.

Since Miller and Modigliani's [3] study, researchers have relaxed the assumption of perfect capital markets and offered theories about how dividend affects the firm value and how managers should formulate dividend policy decisions. Over time, the number of factors identified in the literature as being important to be considered in making dividend decisions increased substantially [2]. Thus, extensive studies have been done to find out various factors affecting dividend payout ratio of a firm.

A variety of variables that might potentially be associated or 'responsible' for the dividend payout in the manufacturing firms can be found in the literature. In this study, the selection of explanatory variables is based on alternative theories related to dividend payout and previous variables that were studied in reported empirical work. The choice is sometimes limited, however, due to lack of relevant data. As a result, the final set of proxy variables includes nine factors: profitability, cash flow, corporate tax, sales growth, marketto-book value ratio, debt-to-equity ratio, dividend payout 
ratios (standard dividend payout ratio and adjusted dividend payout ratio) of the firm, and industry.

Previous studies conducted by different authors $[1,2]$ did not test the impact of depreciation on the dividend payout ratios. The earnings that appear in the denominator of the dividend payout ratios are affected by the reported accounting depreciation.

Based on the different nature of service and manufacturing industries, the results related to dividend payout ratios are expected to be different. For example, investment in machinery and equipment is almost nonexistent in the service industry [7].

Service sector is a more human intensive sector and do not require huge capital asset base like manufacturing companies for their operations. The major asset of this sector is manpower. Therefore the funds required for recruitment and retention of manpower is comparatively less than funds required for purchasing capital assets [2]. So these firms can easily release funds for payment of dividends. Thus, it can be concluded that service firms have high liquidity and it is an important determinant of dividend payout ratio. Since the profitability of the companies is also high so even if there is year to year variability in the earnings of the firms, they can easily pay huge dividends.

The depreciation allowance, however, is higher in the manufacturing industries than the service industry which, in turn, can impact on dividend payout ratios. In the present study, therefore, the depreciation was added back into the net income in order to net out the impact of depreciation on the dividend payout ratios. In addition, we used the market price of the share from the beginning of the year instead of current share price. The variables, together with theoretical predictions as to the direction of their influence on dividend payout ratios are summarized in Table $\mathbf{1}$.

\section{DETERMINANTS OF DIVIDEND PAYOUT RATIOS}

Among factors that may be instrumental in affecting the dividend payout decision, based on the literature we can mention the followings:

\section{Corporate Profitability}

Corporate profitability has long been regarded as the primary indicator of a firm's capacity to pay dividends. Linter [8] and Baker et al. [9] indicate that the dividend payment pattern of a firm is influenced by the current year's earnings and previous year's dividends.

Baker et al. [9] found that the anticipated level of future earnings is the determinant of dividend payment. Pruitt and Gitman [10] in their study report that current and past years' profits are important factors in influencing dividend payments. Baker and Powell [11] concluded from their survey of NYSE-listed firms that dividend determinants are industry specific and anticipated level of future earnings is the major determinant. Amidu and Abor [1] found a positive relationship between corporate profitability and dividend payout ratios. Anil and Kapoor [2] indicate that profitability has always been considered as a primary indicator of dividend payout ratio. Brook et al. [12] explicitly stated that there is no reason to believe that corporate dividend policy is driven by a single goal.

\section{Cash Flow}

The cash flow position of a firm is an important determinant of dividend payouts. A poor liquidity position means less generous dividend due to shortage of cash. Alli et al. [13] argues that dividend payments depend more on cash flows, which reflect the company's ability to pay dividends, than on current earnings, which are less heavily influenced by accounting practices. They claim that current earnings do not really reflect the firm's ability to pay dividends. Amidu and Abor [1] found a positive relationship between cash flow and dividend payout ratios. Anil and Kapoor [2] also indicate that cash flow is an important determinant of dividend payout ratio.

\section{Tax}

Tax-adjusted models presume that investors require and secure higher expected returns on shares of dividend-paying stocks. The consequence of tax-adjusted theory is the division of investors into dividend tax clientele. Modigliani [14] argues that the clientele effect is responsible for the alterations in portfolio composition. Masulis and Trueman's [15] model predicts that investors with differing tax liabilities will not be uniform in their ideal firm dividend policy. They conclude that as tax liability increases (decreases), the preference for dividend payment also increases (decreases). Tax-adjusted model assumes that investors maximize after-tax income. As far back as 1967, Farrar and Selwyn [16] concluded that in a partial equilibrium framework, individual investors choose the amount of personal and corporate leverage and also whether to receive corporate distributions as dividends or capital gain. Recently Amidu and Abor [1] found a positive relationship between tax and dividend payout ratios.

\section{Sales Growth}

Sales growth may impact on dividend payout ratios. Dividend payout levels are not totally decided after a firm's investment and financing decisions have been made [1]; rather, the dividend decision is taken along investment and financing decisions. Partington [17] points out that firms' use of target payout ratios, firms' motives for paying dividends, and the extent to which dividends are determined are independent of investment policy.

Higgins [18] shows a direct link between growth and financing needs of a firm. Rapidly growing firms require external financing because working capital needs normally exceed the incremental cash flows from new sales. In an earlier paper Higgins [19] argues that payout ratio is negatively related to a firm's need for funds to finance growth opportunities. Rozeff [20], Lloyd et al. [21], Collins et al. [22], and recently Amidu and Abor [1], all show a significantly negative relationship between historical sales growth and dividend payout.

\section{Market-to-Book Value}

Market-to-book ratio reflects the market view of the value of equity in comparison to what shareholders have contributed to the firm since the day it was established. Omran and Pointon [23] points that market-to-book ratio is an important factor that influence dividend payout ratio, and 
Amidu and Abor [1] found a negative relationship between market-to-book ratio and dividend payout ratios.

\section{Debt to Equity Ratio}

The debt-to-equity ratio is a financial ratio that indicates the relative proportion of equity and debt used to finance a company's assets. This ratio is also known as risk, gearing or leverage. Pruitt and Gitman [10] indicate that risk affects firms' dividend policy. Firms with high growth rates and high dividend payout ratios utilize debt financing and firms with high leverage compared to their respective industry [24]. Dhillon [25], however, found conflicting evidence for the relationship between dividend payout ratios and leverage. In some industries payout and leverage ratios are positively related while in other industries the relationship is negative. Rozeff [20], Lloyd et al. [21], and Collins et al. [22] found statistically significant and negative relationship between firm's risk and the dividend payout ratios. Their findings suggest that firms having a higher level of risk will pay out dividends at lower rate. D'Souza [26] also finds statistically significant and negative relationship between risk and dividend payout.

In summary, the literature review points out to the fact that corporate profitability, cash flow, tax, sales growth, market-to-book ratio, and debt-to-equity ratio may impact upon the dividend payout ratio. Previous researchers concentrated on the determinants of 'standard ratio of dividend to earnings, or the 'standard dividend payout ratio.' This study examines the determinants of the 'standard dividend payout ratio' and also the extended payout ratio whereby the denominator of the ratio includes net income and depreciation. The difference between the two ratios is grater for the manufacturing industry that usually has relatively high levels of depreciation, in comparison to the service industry. Clearly depreciation costs may have an impact on the dividend payout ratios. Table $\mathbf{1}$ below summarizes the definitions and theoretical predicted signs.

\section{METHODOLOGY AND DATA}

\section{Measurement}

To remain consistent with previous studies, measures pertaining to corporate profitability, cash flow, tax, sales growth, market-to-book ratio, and dividend payout ratios were adopted from Amidu and Abor's [1] study. Measures pertaining to debt-to-equity ratio were taken from Myers and Bacon's [27] study. The study applied co-relational and nonexperimental research design. The process of measurement is central to quantitative research because it provides the fundamental connection between empirical observation and mathematical expression of quantitative relationships.

The dividend payout (PAYOUT) can be modeled as follows:

PAYOUT $_{\mathrm{i}}=\mathrm{b}_{0}+\mathrm{b}_{1} * \mathrm{PROF}_{\mathrm{i}}+\mathrm{b}_{2}{ }^{*} \mathrm{CASH}_{\mathrm{i}}+\mathrm{b}_{3} * \mathrm{TAX}_{\mathrm{i}}+$ $\mathrm{b}_{4} * \mathrm{GROW}_{\mathrm{i}}+\mathrm{b}_{5} * \mathrm{MTBV}_{\mathrm{i}}+\mathrm{b}_{6} * \mathrm{D} / \mathrm{E}_{\mathrm{i}}+\mu_{\mathrm{i}, \mathrm{t}}$

where $b_{0}$ denotes the intercept of the regression equation, and $b_{1}, b_{2}, b_{3}, b_{4}, b_{5}$, and $b_{6}$ are the regression coefficients of PROF, CASH, TAX, GROW, MTBV, and D/E.

\section{Sample and Procedures}

The study constructed a database from a selection of approximately 500 financial-reports announced by public companies in year 2007. The selection was drawn from Mergent Online [http://www.mergentonline.com/compsearch. asp] to draw a random sample of service and manufacturing companies. Out of approximately 500 financial-reports announced by public companies in 2007 , only 266 financial reports were usable.

\section{Data Collection}

Numerical (quantitative) and financial data were collected to test the hypothesis. Financial statements and proxies submitted by companies to Securities and Exchange Board of USA were used to collect data.

\section{Descriptive Statistics}

Table 2 provides the descriptive statistics for all the regression variables. This shows the average indicators of variables computed from the financial statements. The average standard dividend payout ratio (measured as yearly dividends divided by net income after tax) is 26.80 percent and the average profitability is 9.40 percent. This means, on the average, firms pay about 27 percent of their profits as dividends. The average adjusted dividend payout ratio (measured as yearly dividends divided by net income after tax plus depreciation) is 5.40 percent.

Table 1. Proxy Variables Definition and Predicted Relationship

\begin{tabular}{|c|c|c|}
\hline Proxy Variables & Definitions & Predicted Sign \\
\hline Profitability (PROF) & Earnings before interest and taxes/Total assets & $+/-$ \\
\hline Cash Flow (CASH) & Log of cash flow from operating activities & $+/-$ \\
\hline Corporate Tax (TAX) & Corporate tax/Net profit before tax & $+/-$ \\
\hline Sales Growth (GROW) & (Current sales - Previous sales)/Previous sales & $+/-$ \\
\hline Market-to-Book Value (MTBV) & Share price beginning of the year/Net asset value per share-basic & $+/-$ \\
\hline Debt to Equity Ratio (D/E) & Total liabilities/Shareholders' equity & $+/-$ \\
\hline Standard Dividend Payout Ratio (STANDARD PAYOUT) & Yearly dividends/Net income after tax & $+/-$ \\
\hline Adjusted Dividend Payout Ratio (PAYOUT) & Yearly dividends/(Net income after tax + Depreciation) & $+/-$ \\
\hline Industry & Firm is assigned value one if firm is a manufacturing firm and zero otherwise & $+/-$ \\
\hline
\end{tabular}


Table 2. Descriptive Statistics of Independent, Dependent, and Control Variables

\begin{tabular}{|c|c|c|c|c|}
\hline \multicolumn{5}{|c|}{ Descriptive Statistics $(\mathrm{N}=\mathbf{2 6 6})$} \\
\hline Variables & Min & Max & Mean & Std \\
\hline Profitability (PROF) & -0.700 & 0.450 & 0.094 & 0.093 \\
\hline Cash Flow (CASH) & 2.850 & 8.820 & 5.639 & 0.935 \\
\hline Corporate Tax (TAX) & 0.000 & 0.920 & 0.308 & 0.115 \\
\hline Sales Growth (GROW) & -0.440 & 1.730 & 0.122 & 0.196 \\
\hline Market-to-Book Value (MTBV) & -10.710 & 38.460 & 2.892 & 3.597 \\
\hline Debt to Equity Ratio (D/E) & -4.760 & 25.800 & 1.898 & 2.454 \\
\hline Standard Dividend Payout Ratio (STANDARD PAYOUT) & -0.470 & 13.460 & 0.268 & 0.895 \\
\hline Adjusted Dividend Payout Ratio (PAYOUT) & -0.040 & 0.890 & 0.054 & 0.098 \\
\hline
\end{tabular}

All variables were calculated using book value.

Profitability $(\mathbf{P R O F})=$ Earnings before interest and taxes divided by total assets for firm $\mathrm{i}$.

Cash Flow $($ CASH $)=$ Log of net cash flows from operating activities for firm $i$.

Corporate $\operatorname{Tax}($ TAX $)=$ Corporate tax divided by profit before tax for firm $\mathrm{i}$.

Sales Growth $($ GROW $)=$ Growth in sales for firm i.

Market-to-Book Value $(\mathbf{M T B V})=$ Market-to-book value for firm i.

Debt to Equity Ratio $(\mathbf{D} / \mathbf{E})=$ Debt-to-equity ratio for firm i.

Standard Dividend Payout Ratio (STANDARD PAYOUT) = Yearly dividends divided by net income after tax for firm i.

Adjusted Dividend Payout Ratio (PAYOUT) = Yearly dividends divided by net income after tax plus depreciation for firm i.

The cash flow determined as natural logarithm of net cash flows from operating activities has a mean of 5.64. The average corporate tax (measured as corporate tax divided by profit before tax) is 30.80 percent. The average growth rate in sales is 12.20 percent and the average market-to-book value for the firms is 2.89 . The average debt to equity ratio for the firms is 1.90 .

\section{Empirical Study}

Test for multi-colinearity: All variance inflation factor (VIF) coefficients are less than 2 and tolerance coefficients are greater than 0.5 (see Table 3 ).

\section{DISCUSSION}

\section{Corporate Profitability}

Amidu and Abor [1] and Anil and Kapoor [2] found a positive relationship between profitability and dividend payout ratios. We found i) a negative relationship between PROF and STANDARD PAYOUT in the entire sample, ii) a positive relationship between PROF and PAYOUT in the entire sample, iii) a positive relationship between PROF and PAYOUT in the service industry, and iv) a negative relationship between PROF and STANDARD PAYOUT in the manufacturing industry. The findings of this paper lend some support to the findings of Amidu and Abor [1], Anil and Kapoor [2], and Baker and Powell [11].

As expected different results were found for the two different industries. This supports the findings of Baker and Powell's [11] study in which they concluded that dividend determinants are industry specific.

\section{Cash Flow}

Alli et al. [13], Amidu and Abor [1], and Anil and Kapoor [2] found a positive relationship between cash flow and dividend payout ratios. We found no significant relationship between cash flow and dividend payout ratios, contrary to our conjectures.

\section{Tax}

Amidu and Abor [1] found a positive relationship between tax and dividend payout ratio. We found a positive relationship between TAX and STANDARD PAYOUT in the entire sample and in the manufacturing industry. The relationships between STANDARD PAYOUT and all other variables were non-significant. These finding lend some support to the findings of Amidu and Abor [2].

\section{Sales Growth}

As stated above, previous empirical studies [1, 19-22] found a significantly negative relationship between historical sales growth and dividend payout. We found i) a negative relationship between GROW and STANDARD PAYOUT in the entire sample and in the service industry and ii) a negative relationship between GROW and PAYOUT in the entire sample and in the service industry. The findings of this paper are consistent with those of the previous authors' [1, 19-22]. As expected, different results were found between two industries, probably because the service industry has an after tax cash flow that is closer to the net income, in comparison to the manufacturing industry. Furthermore, there were differences between the two industries in the Adjusted Dividend Payout Ratios relationships. This is due to the fact that we added back depreciation to the denominator of the ratio and since the manufacturing industry has typically large levels of depreciation, the difference between the standard and the adjusted payout ratio for the manufacturing industry is larger.

\section{Market-to-Book Value}

D'Souza [26] and Amidu and Abor [1] found a negative relationship between market-to-book ratio and dividend payout ratio. When we measured the 'standard payout ratio' we found no significant relationship at all, either for the entire sample of for each of the two industries. We did find a highly significant positive relationship between the marketto-book ratio and the adjusted dividend payout ratio for the 
Table 3. OLS Regression Estimates on Factors Affecting Profitability (The First Three Parts Refer to the 'Standard Payout' and the Last Three to the 'Adjusted Dividend Payout' Ratios as the Dependent Variable)

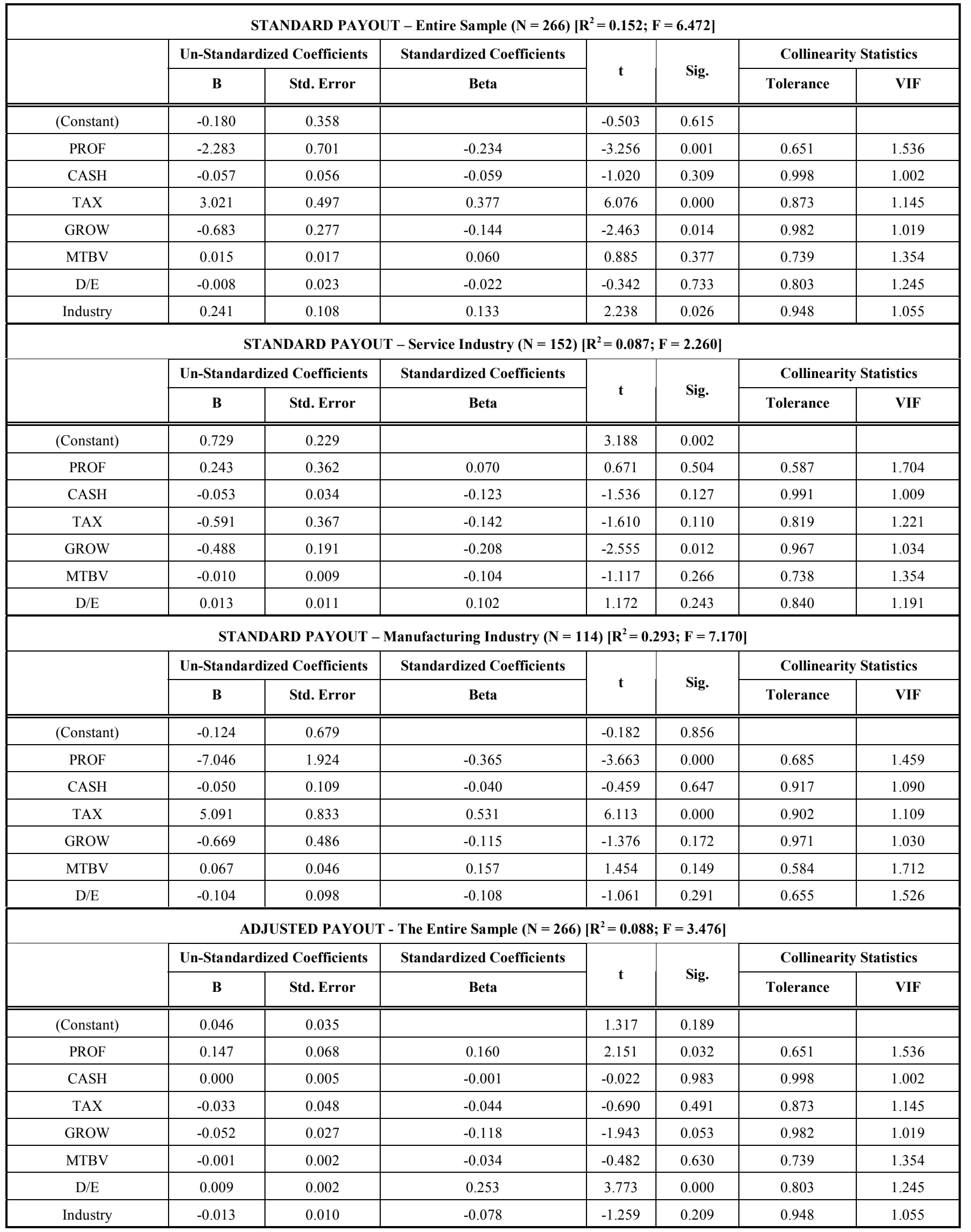


(Table 3) contd.....

\begin{tabular}{|c|c|c|c|c|c|c|c|}
\hline \multicolumn{8}{|c|}{ ADJUSTED PAYOUT - Service Industry Sample $(N=152)\left[R^{2}=0.113 ; F=3.041\right]$} \\
\hline & \multicolumn{2}{|c|}{ Un-Standardized Coefficients } & \multirow{2}{*}{$\begin{array}{c}\text { Standardized Coefficients } \\
\text { Beta }\end{array}$} & \multirow{2}{*}{$\mathbf{t}$} & \multirow{2}{*}{ Sig. } & \multicolumn{2}{|c|}{ Collinearity Statistics } \\
\hline & B & Std. Error & & & & Tolerance & VIF \\
\hline (Constant) & 0.104 & 0.062 & & 1.685 & 0.094 & & \\
\hline PROF & 0.191 & 0.098 & 0.201 & 1.959 & 0.052 & 0.587 & 1.704 \\
\hline $\mathrm{CASH}$ & -0.009 & 0.009 & -0.076 & -0.962 & 0.338 & 0.991 & 1.009 \\
\hline TAX & -0.050 & 0.099 & -0.044 & -0.506 & 0.614 & 0.819 & 1.221 \\
\hline GROW & -0.100 & 0.052 & -0.155 & -1.933 & 0.055 & 0.967 & 1.034 \\
\hline MTBV & -0.003 & 0.002 & -0.119 & -1.295 & 0.198 & 0.738 & 1.354 \\
\hline $\mathrm{D} / \mathrm{E}$ & 0.010 & 0.003 & 0.306 & 3.565 & 0.000 & 0.840 & 1.191 \\
\hline \multicolumn{8}{|c|}{ ADJUSTED PAYOUT - Manufacturing Industry Sample $(N=114)\left[R^{2}=0.153 ; F=3.121\right]$} \\
\hline & \multicolumn{2}{|c|}{ Un-Standardized Coefficients } & Standardized Coefficients & \multirow{2}{*}{$\mathbf{t}$} & \multirow{2}{*}{ Sig. } & \multicolumn{2}{|c|}{ Collinearity Statistics } \\
\hline & B & Std. Error & Beta & & & Tolerance & VIF \\
\hline (Constant) & 0.012 & 0.029 & & 0.394 & 0.695 & & \\
\hline PROF & -0.064 & 0.083 & -0.083 & -0.762 & 0.448 & 0.685 & 1.459 \\
\hline CASH & 0.004 & 0.005 & 0.084 & 0.895 & 0.373 & 0.917 & 1.090 \\
\hline TAX & -0.011 & 0.036 & -0.029 & -0.310 & 0.757 & 0.902 & 1.109 \\
\hline GROW & -0.009 & 0.021 & -0.040 & -0.440 & 0.661 & 0.971 & 1.030 \\
\hline MTBV & 0.007 & 0.002 & 0.422 & 3.571 & 0.001 & 0.584 & 1.712 \\
\hline $\mathrm{D} / \mathrm{E}$ & -0.004 & 0.004 & -0.109 & -0.979 & 0.330 & 0.655 & 1.526 \\
\hline
\end{tabular}

Dependent Variables: i) STANDARD PAYOUT and ii) PAYOUT

STANDARD PAYOUT = Dividend payout ratio [Yearly dividends divided by net income after tax for firm i]

PAYOUT $=$ Adjusted dividend payout ratio [Yearly dividends divided by net income after tax plus depreciation for firm i].

PROF $=$ Profitability

CASH $=$ Cash Flow

TAX $=$ Corporate tax.

GROW $=$ Sales Growth

MTBV $=$ Market-to-book value

$\mathbf{D} / \mathbf{E}=$ Debt-to-equity ratio.

Industry $=$ Firm was assigned value one if firm was a manufacturing firm and zero otherwise.

$\mathbf{N}=$ Number of usable companies.

manufacturing industry. Our findings contradict the findings of D'Souza [26] and Amidu and Abor [1], perhaps because they did not add back depreciation costs into the net income after tax, and thus did not refer to the dividend/net cash flow concept that may be a more relevant indicator of 'dividend policy.'

\section{Debt to Equity Ratio}

Previous empirical studies [20-22, 26] reported a negative relationship between firm's risk and the dividend payout ratios. We found neither significant relationship between the $\mathrm{D} / \mathrm{E}$ ratio and the 'standard' dividend payout ratio in the entire sample nor in each of the two industries. When the Adjusted dividend payout ratio was defined as the dependent variable, we found that for the entire sample there is a positive relationship between $\mathrm{D} / \mathrm{E}$ and dependent variable, and for both the service and the manufacturing industries.

\section{CONCLUSION}

This study examined the determinants of dividend payout ratios of American service and manufacturing firms. We found, inter alia, that the view of the dividend payout ratio on an adjusted basis, namely the ratio between the cash dividend that the net cash flow generated by the firm gave rise to results that are different from those obtained with the 'usual' dividend payout ratio as the dependent variable. We also found that some of the relationships between the independent variable and the dependent variable for manufacturing firms are different from those for firms in the service industry.

\section{LIMITATIONS OF THE RESEARCH}

Because this study was co-relational and nonexperimental (i.e., none of the participating firms will be assigned to conditions) a causal link between independent variable (e.g., sales growth) and dependent variable (e.g., dividend payout ratio) cannot be definitively established. Therefore, a link between independent variable (e.g., sales growth) and dependent variable (e.g., dividend payout ratio) can only be suggested. Additionally, the findings of this study can only be generalized to firms similar to those who participated in the research.

\section{FUTURE RESEARCH}

Future research should investigate generalization of the findings beyond the United States. The influence of priceearning-ratio and debt-to-equity ratio on dividend payout 
policy should be investigated in the future study. In addition, future research may examine the non-linear relationships among independent and dependent variables. Important control variables such as industry sector, etc., should also be used to determine other factors that influence dividend payout ratios.

\section{REFERENCES}

[1] Amidu M, Abor J. Determinants of dividend payout ratios in Ghana. J Risk Finance 2006; 7: 136-45.

[2] Anil K, Kapoor S. Determinants of dividend payout ratios - a study of Indian information technology sector. Int Res J Finance Econ 2008; $15: 1-9$.

[3] Miller MH, Modigliani F. Dividend policy, growth and the valuation of shares. J Bus 1961; 34: 411-33.

[4] Black F. The dividend puzzle. J Portfolio Manage 1976; 2: 5-8.

[5] Bernstein PL. Dividends: the puzzle. J Appl Corp Finance 1996; 9: 4-15.

[6] Aivazian V, Booth L. Do emerging market firms follow different dividend policies from US firms? J Finance Res 2003; 26: 371-87.

[7] Gill A, Biger N, Pai C, Bhutani S. The determinants of capital structure in the service industry: evidence from United States. Open Bus J 2009; 2: 48-53.

[8] Linter J. Distribution of incomes of corporations among dividends, retained earnings and taxes. Am Econ Rev 1956; 46: 97-113.

[9] Baker HK, Farrelly GE, Edelman RB. A survey of management views on dividend policy. Finance Manage 1985; 14: 1007-34.

[10] Pruitt SW, Gitman LW. The interactions between the investment, financing, and dividend decisions of major US firms. Finance Rev 1991; 26: 409-30.

[11] Baker HK, Powell GE. Determinants of corporate dividend policy: a survey of NYSE firms. Finance Pract Educ 2000; 9: 29-40.

[12] Brook Y, Chalton W, Hendershott R. Do firms use dividends to signal large future cash flow increase? Finance Manage 1998; 27: 46-57.
[13] Alli K, Khan A, Ramirez G. Determinants of dividend policy: a factorial analysis. Finance Rev 1993; 28: 523-47.

[14] Modigliani F. Debt, dividend policy, inflation and market valuation. J Finance 1982; 37: 255-73.

[15] Masulis RW, Trueman B. Corporate investment and dividend decisions under differential personal taxation. J Finance Quant Anal 1988; 23: 369-86.

[16] Farrar DE, Selwyn LL. Taxes, corporate financial policy and return to investors. Nati Tax J 1967; 20: 444-62.

[17] Partington GH. Why firms use payout target: a comparative study of dividend policies. Paper presented at AAANZ Conference, Brisbane 1983.

[18] Higgins RC. Sustainable growth under inflation. Finance Manage 1981; 10: 36-40.

[19] Higgins RC. The corporate dividend-saving decision. J Finance Quant Anal 1972; 7: 1527-41.

[20] Rozeff SM. Growth, beta and agency cost as determinants of dividend payout ratios. J Finance Res 1982; 5: 411-33.

[21] Lloyd WP, Jahera SJ, Page DE. Agency cost and dividend payout ratios. Q J Bus Econ 1985; 24: 19-29.

[22] Collins MC, Saxena AK, Wansley JW. The role of insiders and dividend policy: a comparison of regulated and unregulated firms. J Finance Strategic Dec 1996; 9:1-9.

[23] Omran M, Pointon J. Dividend policy, trading characteristics, and share prices: empirical evidence from Egyptian firms. Int. J Theor Appl Finance 2004; 7: 121-30.

[24] Chehab AF. Essays on the determinants of capital structure. University of New Orleans 1995.

[25] Dhillon UP. Corporate ownership, dividend policy, and capital structure under asymmetric information. Louisiana State University and Agricultural \& Mechanical College 1986.

[26] D'Souza J. Agency cost, market risk, investment opportunities and dividend policy an international perspective. Managerial Finance 1999; 25: 35-43.

[27] Myers M, Bacon F. The determinants of corporate dividend policy. Allied Academies International Conference. Acad Account Finance Stud 2002; 7: 105-10. 